\title{
Role of Deformation-Induced Martensite in TRIP Effect of Metastable Austenitic Steels
}

\author{
Noriyuki TSUCHIDA, ${ }^{1) *}$ Eiichiro ISHIMARU ${ }^{2)}$ and Masatomo KAWA ${ }^{2)}$ \\ 1) Graduate School of Engineering, University of Hyogo, 2167 Shosha, Himeji, 671-2280 Japan. \\ 2) Research \& Development Center, Nippon Steel Stainless Steel Corporation, 3434 Shimata, Hikari-City, $743-8550$ Japan.
}

(Received on May 1, 2020; accepted on June 10, 2020)

\begin{abstract}
Role of deformation-induced martensite in the transformation-induced plasticity (TRIP) of metastable austenitic steels was studied by examining effects of temperature on the tensile properties of $\mathrm{Fe}-18 \% \mathrm{Cr}$ $6 \% \mathrm{Ni}-0.2 \% \mathrm{~N}-0.1 \% \mathrm{C}(6 \mathrm{Ni}-0.2 \mathrm{~N}-0.1 \mathrm{C})$ steel. The tensile properties obtained by tensile tests at various temperatures between 123 and $373 \mathrm{~K}$ were compared with those of SUS304 steel. The $0.2 \%$ proof stress, tensile strength, and uniform elongation of the $6 \mathrm{Ni}-0.2 \mathrm{~N}-0.1 \mathrm{C}$ steel were larger than those of SUS304 at all temperature studied, and the mechanical stability of the austenite for the $6 \mathrm{Ni}-0.2 \mathrm{~N}-0.1 \mathrm{C}$ steel was higher than that for the SUS304 steel. Neutron diffraction experiments at room temperature showed that the improvements in the mechanical properties in the $6 \mathrm{Ni}-0.2 \mathrm{~N}-0.1 \mathrm{C}$ steel were associated with larger work hardening of the austenite and larger strength of the deformation-induced martensite. The increase in strength of deformation-induced martensite with $\mathrm{N}$ and $\mathrm{C}$ additions leads to better mechanical properties due to the TRIP effect, despite of smaller amounts of deformation-induced martensitic transformation.
\end{abstract}

KEY WORDS: TRIP; metastable austenitic stainless steel; deformation-induce martensite; N; C.

\section{Introduction}

The transformation-induced plasticity (TRIP) effect is a strengthening mechanism in which an enhancement of elongation can be obtained by using a deformation-induced martensitic transformation (DIMT). ${ }^{1-3)}$ Various studies on the TRIP effect in metastable austenitic stainless steels, ${ }^{1,3-6)}$ TRIP-aided multi-microstructure steels, ${ }^{2,7-10)}$ and other steels have been reported. We have also paid attention to the role of the DIMT in the TRIP effect, and have investigated the effects of temperature, ${ }^{11,12)}$ strain rate, ${ }^{12,13)}$ and $\mathrm{Ni}$ equivalent (chemical composition) ${ }^{14)}$ on the TRIP effect in metastable austenitic stainless steels. It is well known that the DIMT behavior usually plays an important role in the TRIP effect. ${ }^{1,3,8,10)}$ Numerous studies on the TRIP effect in relation to the control of DIMT behavior have been reported. ${ }^{1,3,7-11)}$

On the other hand, it is also important to consider the role of the strength of deformation-induced martensite in the TRIP effect. For example, Harjo et al. estimated from in situ neutron diffraction experiments that the strength of deformation-induced martensite in a TRIP-aided multimicrostructure steel (TRIP steel) was about 2 to $2.5 \mathrm{GPa}^{15}$ ) The strength of deformation-induced martensite, through

\footnotetext{
* Corresponding author: E-mail: tsuchida@eng.u-hyogo.ac.jp
}

the TRIP effect, appears to play a key role in enhancing uniform elongation in TRIP steels whose volume fractions of retained austenite are about $10 \%$. Tsuchida et al. studied the effect of temperature on the mechanical properties of a lean duplex stainless steel, and they reported that the increase in uniform elongation due to the TRIP effect was nearly identical to that in SUS304 and SUS301L steels. ${ }^{16)}$ Fujisawa et al. also studied the effects of $\mathrm{Ni}$ and $\mathrm{N}$ on the stability of austenite and on the tensile properties of duplex stainless steels at various temperatures. ${ }^{17)}$ The better uniform elongation and high tensile strength of these duplex stainless steel appears to be associated with the presence of hard deformation-induced martensite. Because $\mathrm{N}$ is present instead of $\mathrm{Ni}$ in lean duplex stainless steels, the deformation behavior of their austenite phase can be expected to improve. ${ }^{16,18)}$

There have been many studies on the effects of $\mathrm{N}$ and $\mathrm{C}$ on the mechanical stability and mechanical properties of austenite steels. Lee et al. studied the tensile deformation behavior of $18 \mathrm{Cr}-10 \mathrm{Mn}$ steels with $\mathrm{N}$ contents of $0.33-0.51$ mass $\%$ at room temperature (RT). ${ }^{19)}$ They found that the mechanical stability of the austenite increased with increasing $\mathrm{N}$ content and that no DIMT occurred at RT for a $\mathrm{N}$ content of 0.51 mass $\%$. Miura et al. prepared austenitic stainless steels with $\mathrm{N}$ contents of $0.05-0.18$ mass $\%$ and a C content of 0.085 mass $\%$ based on SUS304 and SUS316 
steels and they investigated the tensile deformation behavior of these steels at RT, $77 \mathrm{~K}$ and $4 \mathrm{~K} .{ }^{20)}$ The $0.2 \%$ proof stress increased with increasing $\mathrm{N}$ and $\mathrm{C}$ contents, and the elongation showed a maximum value at about $\mathrm{M}_{\mathrm{d} 30}$ (the temperature at which $50 \%$ austenite transforms into martensite with $30 \%$ true strain). Yoshitake et al. investigated the effect of $\mathrm{N}$ and $\mathrm{C}$ on the work hardening behavior of austenitic stainless steels, ${ }^{21)}$ and Masumura et al. made a detailed studied of the effects of the addition of $\mathrm{N}$ and $\mathrm{C}$ on the stability of austenite ${ }^{22)}$ and also proposed a modified equation that takes into account the effects of $\mathrm{N}$ and $\mathrm{C}$ on the $\mathrm{M}_{\mathrm{d} 30 .}{ }^{23)}$ However, there have been few quantitative studies on the role of deformation-induced martensite in the TRIP effect from the viewpoint of the strength of deformationinduced martensite.

Therefore, to clarify the role of deformation-induced martensite in the TRIP effect, we studied the tensile deformation behavior of a metastable austenitic steel containing added $\mathrm{N}$ and $\mathrm{C}$. The test temperatures covered a wide range from 123 to $373 \mathrm{~K}$ to clarify changes in mechanical properties and various DIMT behaviors. Furthermore, we conducted neutron diffraction experiments at RT by using the metastable austenitic steel and SUS304, and we discuss their TRIP effects from the viewpoints of the tensile deformation behavior of deformation-induced martensite.

\section{Experimental Procedures}

In this study, we examined two types of metastable austenitic stainless steel: $6 \mathrm{Ni}-0.2 \mathrm{~N}-0.1 \mathrm{C}$ steel and JISSUS304 steel. ${ }^{11)}$ Table 1 lists the chemical compositions of these two steels. The $\mathrm{Ni}$ content of the $6 \mathrm{Ni}-0.2 \mathrm{~N}-0.1 \mathrm{C}$ steel was 2 mass\% lower than that of SUS304, and 0.2 mass $\%$ of $\mathrm{N}$ and 0.1 mass $\%$ of $\mathrm{C}$ were added as austenite formers. For the $6 \mathrm{Ni}-0.2 \mathrm{~N}-0.1 \mathrm{C}$ steel, ingots were vacuum melted, hot rolled to a thickness of $4.5 \mathrm{~mm}$, and heated at $1123 \mathrm{~K}$ for $30 \mathrm{~s}$, followed by air cooling. They were then cold rolled to a final thickness of $1.5 \mathrm{~mm}$ and air cooled after heat treatment for $30 \mathrm{~s}$ at $1123 \mathrm{~K}$. Finally, they were annealed at $1323 \mathrm{~K}$ for $1.8 \mathrm{ks}$ and quenched in water. Figure 1 shows an optical micrograph of the $6 \mathrm{Ni}-0.2 \mathrm{~N}-$ $0.1 \mathrm{C}$ steel. The average austenite grain size, as estimated by the conventional linear intercept method, was $55.6 \mu \mathrm{m}$. Tensile test specimens with a gage length of $25 \mathrm{~mm}$ and a gage width of $5 \mathrm{~mm}$ were prepared from those sheets, and static tensile tests were performed at an initial strain rate of $3.3 \times 10^{-4} \mathrm{~s}^{-1}$ at various temperatures between 123 and $373 \mathrm{~K}$ by using a gear-driven Instron machine. ${ }^{11,12)}$ During these tests, the test temperature was controlled by using a constant-temperature bath. To investigate the effects of temperature on the DIMT kinetics, test samples deformed by various amounts of true strain $(\varepsilon)$ were prepared for x-ray diffraction analysis. ${ }^{11,12)}$ Quantitative estimations of the austenite and deformation-induced martensite volume fractions by $\mathrm{x}$-ray diffraction were based on the principle that the total integrated intensity of all the diffraction peaks for each phase in a mixture is proportional to the volume fraction of that phase. ${ }^{12,24)}$

Tensile test specimens for the neutron diffraction experiments at RT were prepared so that the parallel part had a gage length of $55 \mathrm{~mm}$, a gage width of 6
Table 1. Chemical compositions (mass\%) in the $\mathrm{Fe}-18 \mathrm{Cr}-6 \mathrm{Ni}-$ $0.2 \mathrm{~N}-0.1 \mathrm{C}$ and SUS304 steels.

\begin{tabular}{ccccccccc}
\hline & $\mathrm{C}$ & $\mathrm{Si}$ & $\mathrm{Mn}$ & $\mathrm{P}$ & $\mathrm{S}$ & $\mathrm{Ni}$ & $\mathrm{Cr}$ & $\mathrm{N}$ \\
\hline 6Ni-0.2N-0.1C & 0.099 & 0.4 & 0.99 & 0.002 & 0.0004 & 6.0 & 18.2 & 0.20 \\
SUS304 & 0.05 & 0.4 & 0.98 & 0.03 & 0.008 & 8.2 & 18.2 & 0.023 \\
\hline
\end{tabular}

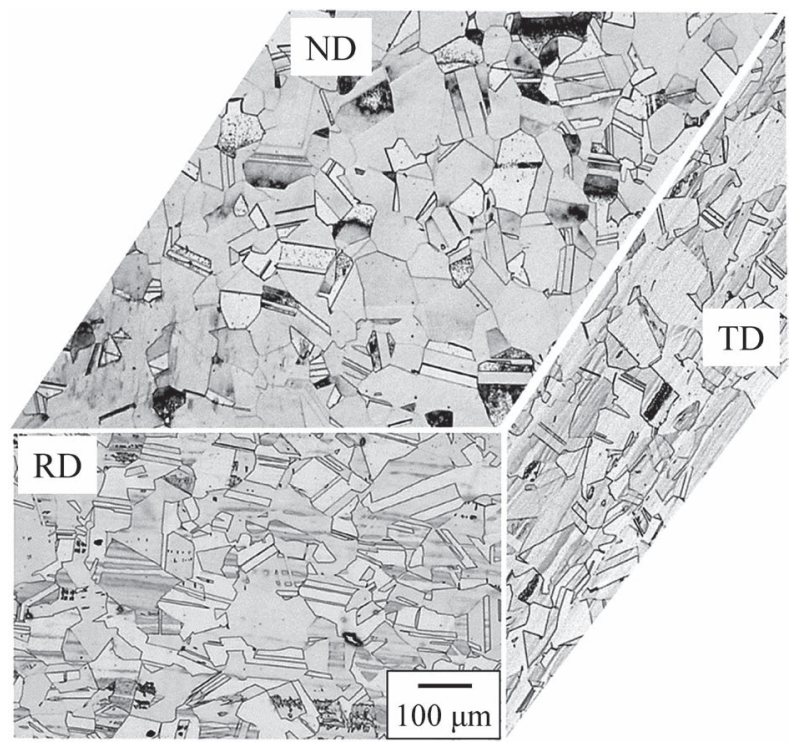

Fig. 1. Optical micrograph of the $6 \mathrm{Ni}-0.2 \mathrm{~N}-0.1 \mathrm{C}$ steel.

$\mathrm{mm}$, and thickness of $1.5 \mathrm{~mm}$. The specimens were mounted horizontally in a loading machine equipped with a time-of-flight-type engineering neutron diffractometer (TAKUMI at J-PARC). ${ }^{15,25,26)}$ Diffraction patterns in the axial and transverse directions were measured simultaneously by using two $90^{\circ}$-scattering detector banks. The neutron diffraction patterns for both the axial and transverse directions were collected at detector areas integrated $\pm 15^{\circ}$ horizontally and $\pm 15^{\circ}$ vertically. Tensile deformations were conducted in a step-load-controlled manner with a $300 \mathrm{~s}$ hold for the elastic regions, and in a continuous manner with an initial strain rate of $5 \times 10^{-4} \mathrm{~s}^{-1}$ for the plastic regions. In the plastic deformation region, the tensile deformation was performed in a stepwise manner for every $\varepsilon$ of about 0.05 , and the diffraction pattern was measured for the unloaded specimen during temporary stops for 600 s. These measurements were repeatedly conducted up to a value close to the maximum load point. From the resulting diffraction patterns, residual lattice strains and volume fractions of the austenite $(\gamma)$ and ferrite $(\alpha)$ phases were calculated. In this study, the data for the $\alpha$ phase were considered to correspond to those of the deformation-induced martensite. Residual phase strain was calculated from the average residual lattice strain of each phase. The residual lattice strain $\left(\varepsilon_{h k l}^{r}\right)$ was calculated by using the following equation, which is based on peak analyses:

$$
\varepsilon_{h k l}^{r}=\frac{d_{h k l}-d_{h k l}^{0}}{d_{h k l}^{0}}
$$

where, $d_{h k l}$ is the lattice spacing after the tensile deformation and $d_{h k l}^{0}$ is the lattice spacing before deformation. The $d_{h k l}^{0}$ of $\gamma$ was obtained from peak analyses before deformation, but 
$\alpha$ does not exist before deformation in this case. The $d_{h k l}^{0}$ of $\alpha$ was estimated by using the following equation:

$$
V_{\gamma} \varepsilon_{\gamma}^{r-p h .}+V_{\alpha} \varepsilon_{\alpha}^{r-p h .}=0
$$

where $\varepsilon_{\gamma}^{r-p h}$ and $\varepsilon_{\alpha}^{r-p h}$ are the residual phase strains of $\gamma$ and $\alpha$, and $V_{\gamma}$ and $V_{\alpha}$ are the volume fractions of $\gamma$ and $\alpha$, respectively. The value of $\varepsilon_{\alpha}^{r-p h}$. at a given $\varepsilon$ can be calculated by using $\varepsilon_{\gamma}^{r-p h .}, V_{\gamma}$ and $V_{\alpha}$. The lattice constant of $\alpha$ before deformation $\left(a_{\alpha}^{0}\right)$ can be calculated from the calculated $\varepsilon_{\alpha}^{r-p h}$. and the lattice constant of $\alpha$ at a given $\varepsilon$, which is obtained as the average of the lattice spacings. Finally, the values of $d_{h k l}^{0}$ of $\alpha$ for each grain were calculated by using $a_{\alpha}^{0}$.

\section{Results and Discussion}

\subsection{Effect of Temperature on the Mechanical Proper- ties of $6 \mathrm{Ni}-0.2 \mathrm{~N}-0.1 \mathrm{C}$ Steel}

Figure 2 shows the nominal stress-strain curves for $6 \mathrm{Ni}-0.2 \mathrm{~N}-0.1 \mathrm{C}$ steel obtained by static tensile tests at various temperatures. The $0.2 \%$ proof stress and the tensile strength (TS) increased with decreasing temperature, and the uniform elongation (U.El) showed a maximum value at $308 \mathrm{~K}$. Figure 3 shows the $0.2 \%$ proof stress, TS, and $\mathrm{U} . \mathrm{El}$ as functions of the temperature for the $6 \mathrm{Ni}-0.2 \mathrm{~N}-$ $0.1 \mathrm{C}$ and SUS304 ${ }^{11)}$ steels. The $0.2 \%$ proof stress and TS for the $6 \mathrm{Ni}-0.2 \mathrm{~N}-0.1 \mathrm{C}$ steel at each temperature examined were larger than those for the SUS304 steel. At any given temperature, the U.El in the $6 \mathrm{Ni}-0.2 \mathrm{~N}-0.1 \mathrm{C}$ steel was also larger than that in the SUS304 steel. The difference in the values of TS was larger at lower temperatures, and that of U.El became larger at temperatures above $273 \mathrm{~K}$. The maximum U.El value for both steels occurred at 308 $\mathrm{K}$. However, the temperature dependences of the $0.2 \%$ proof stresses were different. The $0.2 \%$ proof stress of the SUS304 steel decreased below $243 \mathrm{~K}^{11}{ }^{11}$ whereas that of the $6 \mathrm{Ni}-0.2 \mathrm{~N}-0.1 \mathrm{C}$ steel increased with decreasing temperature, in a similar manner to the TS. This temperature dependence of the $0.2 \%$ proof stress for the SUS304 steel is related to the fact that the $\mathrm{M}_{\mathrm{s}}{ }^{\sigma}$ point of SUS304 steel is $243 \mathrm{~K}^{11)}$ The DIMT was also expected to occur below the $0.2 \%$ proof stress in the $6 \mathrm{Ni}-0.2 \mathrm{~N}-0.1 \mathrm{C}$ steel, but the $0.2 \%$ proof stress increased with decreasing temperature. This temperature dependence of the $0.2 \%$ proof stress has also been observed in SUS301L steel with a $\mathrm{N}$ content of about 0.1 mass $\%{ }^{11,12)}$ As a result of their tensile tests conducted at RT, $77 \mathrm{~K}$ and $4 \mathrm{~K}$, Miura et al. ${ }^{20)}$ reported that the addition of $\mathrm{N}$ up to $0.18 \mathrm{mass} \%$ led to a larger temperature dependence of the $0.2 \%$ proof stress. The results obtained by Miura et al. agreed with our present temperature dependence of the $0.2 \%$ proof stress in the $6 \mathrm{Ni}-0.2 \mathrm{~N}-0.1 \mathrm{C}$ steel. Thus, the temperature dependence of the $0.2 \%$ proof stress for the $6 \mathrm{Ni}-0.2 \mathrm{~N}-0.1 \mathrm{C}$ steel was associated with the higher mechanical stability of $\gamma$, the smaller $V_{\alpha}$ at the $0.2 \%$ proof stress and the larger temperature dependence on $0.2 \%$ proof stress due to the addition of $\mathrm{N}$ in comparison with the SUS304. Figure 4 shows the true stress $(\sigma)$ and workhardening rate $(d \sigma / d \varepsilon)$ as functions of $\varepsilon$ for the $6 \mathrm{Ni}-0.2 \mathrm{~N}-$ $0.1 \mathrm{C}$ steel at various temperatures. As can be seen, $d \sigma / d \varepsilon$ stopped decreasing and began to increase again below 308 $\mathrm{K}$, whereas it decreased with increasing $\varepsilon$ at $373 \mathrm{~K}$. This

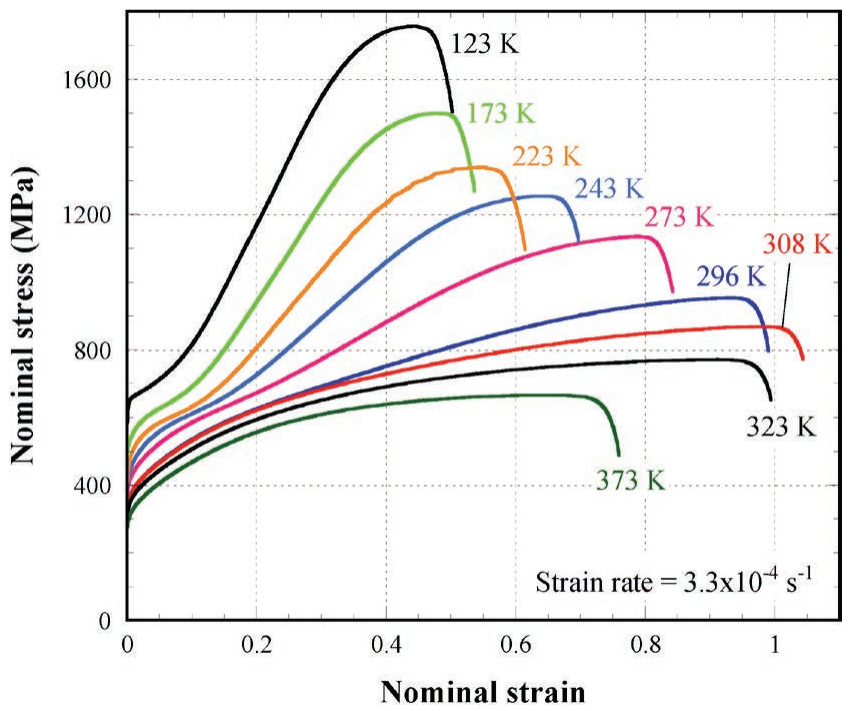

Fig. 2. Nominal stress-strain curves of the $6 \mathrm{Ni}-0.2 \mathrm{~N}-0.1 \mathrm{C}$ steel obtained by the static tensile tests at various temperatures. (Online version in color.)

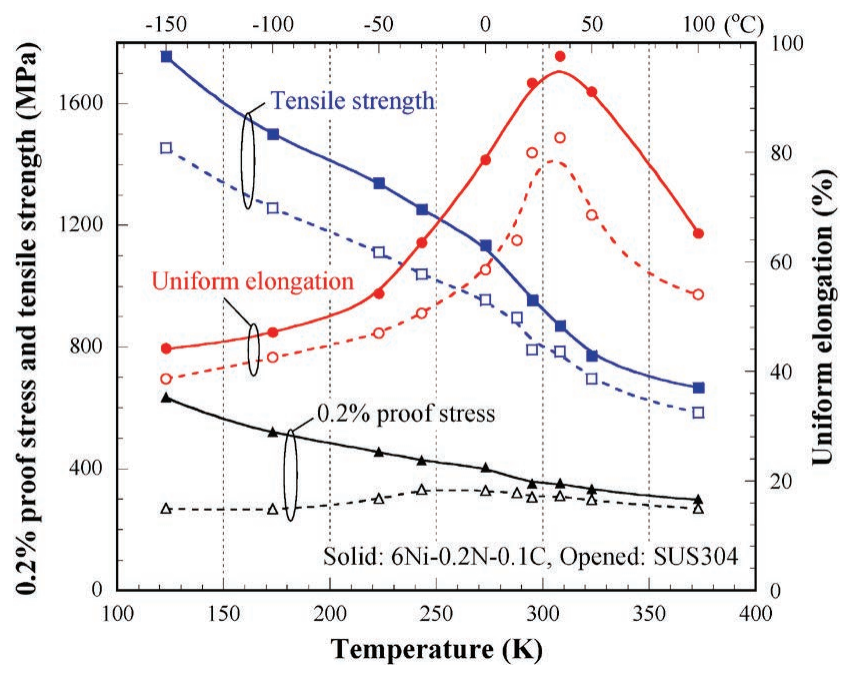

Fig. 3. $0.2 \%$ proof stress, tensile strength and uniform elongation as functions of temperature in the $6 \mathrm{Ni}-0.2 \mathrm{~N}-0.1 \mathrm{C}$ and SUS30 $4^{11)}$ steels. (Online version in color.)

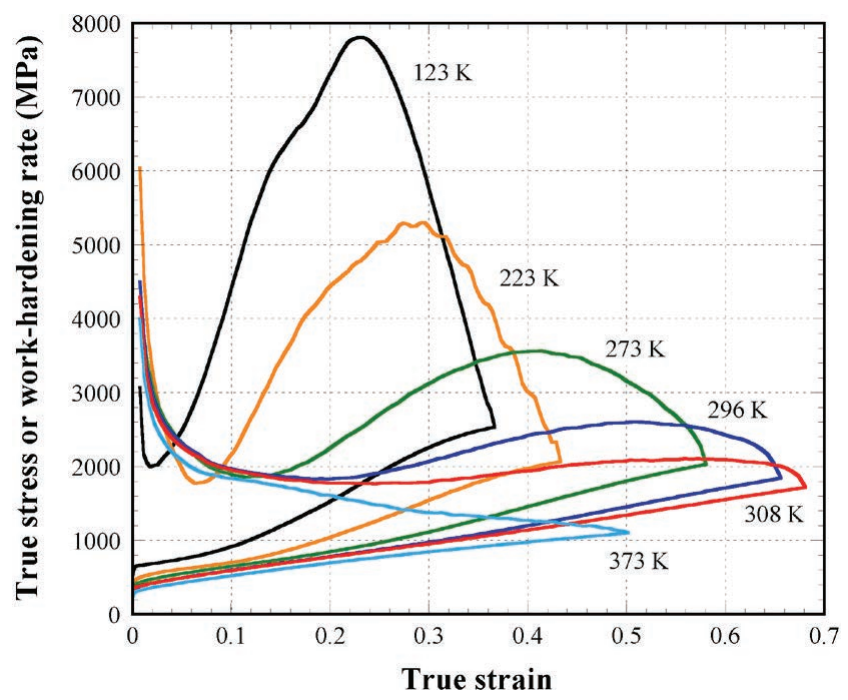

Fig. 4. True stress and work-hardening rate as functions of true strain at various temperatures in the $6 \mathrm{Ni}-0.2 \mathrm{~N}-0.1 \mathrm{C}$ steel. (Online version in color.) 
behavior of $d \sigma / d \varepsilon$ is pronounced at lower temperatures and it has also been reported for SUS304 and SUS301L steels. ${ }^{1,11,12)}$ When the values of $d \sigma / d \varepsilon$ for $6 \mathrm{Ni}-0.2 \mathrm{~N}-0.1 \mathrm{C}$ steel were compared with those for SUS304, ${ }^{11)}$ the value of $d \sigma / d \varepsilon$ at a given $\varepsilon$ was larger in the $6 \mathrm{Ni}-0.2 \mathrm{~N}-0.1 \mathrm{C}$ steel at various temperatures.

\subsection{Effect of Temperature on the Deformation-Induced Martensitic Transformation Behavior of $6 \mathrm{Ni}-0.2 \mathrm{~N}-$ $0.1 \mathrm{C}$ Steel}

Figure 5 shows the volume fraction of deformationinduced martensite at $\varepsilon=0.3$ as a function of temperature in the $6 \mathrm{Ni}-0.2 \mathrm{~N}-0.1 \mathrm{C}$ and SUS304 steels. The temperature for a volume fraction of deformation-induced martensite of $0.5(50 \%)$ is estimated as the $\mathrm{M}_{\mathrm{d} 30}$ point ${ }^{19,23)}$ from Fig. 5. The estimated $\mathrm{M}_{\mathrm{d} 30}$ points of the $6 \mathrm{Ni}-0.2 \mathrm{~N}-0.1 \mathrm{C}$ and SUS304 steels are $258 \mathrm{~K}$ and $278 \mathrm{~K}$, respectively. These estimated $\mathrm{M}_{\mathrm{d} 30}$ points suggest that the mechanical stability of $\gamma$ is higher in the $6 \mathrm{Ni}-0.2 \mathrm{~N}-0.1 \mathrm{C}$ steel. To permit a comparison of the DIMT behaviors of $6 \mathrm{Ni}-0.2 \mathrm{~N}-0.1 \mathrm{C}$ and SUS304 steels in more detail, the $V_{\alpha}$ as a function of $\varepsilon$ at various temperatures are shown in Fig. 6. In Fig. 6, the solid lines $(6 \mathrm{Ni}-0.2 \mathrm{~N}-0.1 \mathrm{C})$ and dashed ones (SUS304) are the calculated results obtained by using the following equation, proposed by Matsumura et al. ${ }^{27)}$

$$
V_{\alpha}=1-\frac{V_{\gamma 0}}{1+(k / q) V_{\gamma 0} \varepsilon^{q}}
$$

where $V_{\gamma 0}$ is the volume fraction of $\gamma$ before deformation, and $k$ and $q$ are constants. ${ }^{27)}$ The value of $V_{\alpha}$ at a given $\varepsilon$ and temperature for the $6 \mathrm{Ni}-0.2 \mathrm{~N}-0.1 \mathrm{C}$ steel was smaller than that for the SUS304 steel. The difference in the values of $V_{\alpha}$ for the $6 \mathrm{Ni}-0.2 \mathrm{~N}-0.1 \mathrm{C}$ and $\mathrm{SUS} 304$ steels increased with increasing temperatures and $\varepsilon$, as shown in Fig. 6. On the basis of Figs. 5 and 6, the mechanical stability of the $\gamma$ in the $6 \mathrm{Ni}-0.2 \mathrm{~N}-0.1 \mathrm{C}$ steel is higher than that in the SUS304 steel. It is interesting that the $6 \mathrm{Ni}-0.2 \mathrm{~N}-0.1 \mathrm{C}$ steel displays

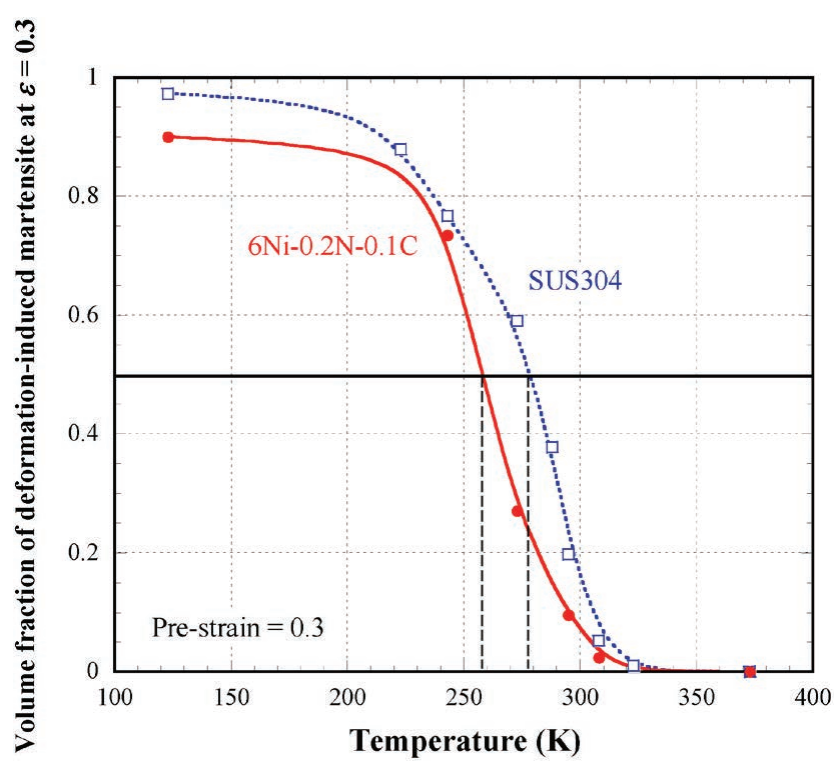

Fig. 5. Volume fraction of deformation-induced matrensite at true strain of 0.3 as a function of temperature in the $6 \mathrm{Ni}-0.2 \mathrm{~N}-$ $0.1 \mathrm{C}$ and SUS304 ${ }^{11)}$ steels. (Online version in color.) better tensile properties than the SUS304 steel, despite its smaller $V_{\alpha}$.

\subsection{Roles of Deformation-Induced Martensite and Austenite on the Stress-Strain Relationship from Neutron Diffraction Experiments}

Figure 7 shows the $\sigma-\varepsilon$ relationships for $6 \mathrm{Ni}-0.2 \mathrm{~N}-0.1 \mathrm{C}$ (a) and SUS304 (b), as determined by neutron diffraction experiments and static tensile tests at RT. The $\sigma-\varepsilon$ relationships between the static tensile test and the neutron diffraction experiment were almost the same for both steels. Figure 8 shows the residual phase strains of $\gamma$ and $\alpha$ (i.e., the deformation-induced martensite) as functions of $\varepsilon$ for the $6 \mathrm{Ni}-0.2 \mathrm{~N}-0.1 \mathrm{C}$ and SUS304 steels, as obtained by neutron diffraction experiments. Here, the residual phase strain was estimated as the average of the residual lattice strain for each phase. The residual phase strain of $\gamma$ is compressive after the onset of DIMT and that of $\alpha$ is tensile. The difference between the residual phase strains of the $\gamma$ and $\alpha$ phases was also larger in the $6 \mathrm{Ni}-0.2 \mathrm{~N}-0.1 \mathrm{C}$ steel. The difference in the residual phase strains is associated with stress partitioning between $\gamma$ and $\alpha$ phases, which leads to work hardening of metastable austenitic stainless steels. ${ }^{10,15,18,28-30)}$ Figure 9 shows a plot of the residual lattice strains of various grains vs. $\varepsilon$ in the $6 \mathrm{Ni}-0.2 \mathrm{~N}-0.1 \mathrm{C}$ (a) and SUS304 (b) steels. On the basis of Fig. 9, it is possible to discuss the work harden-

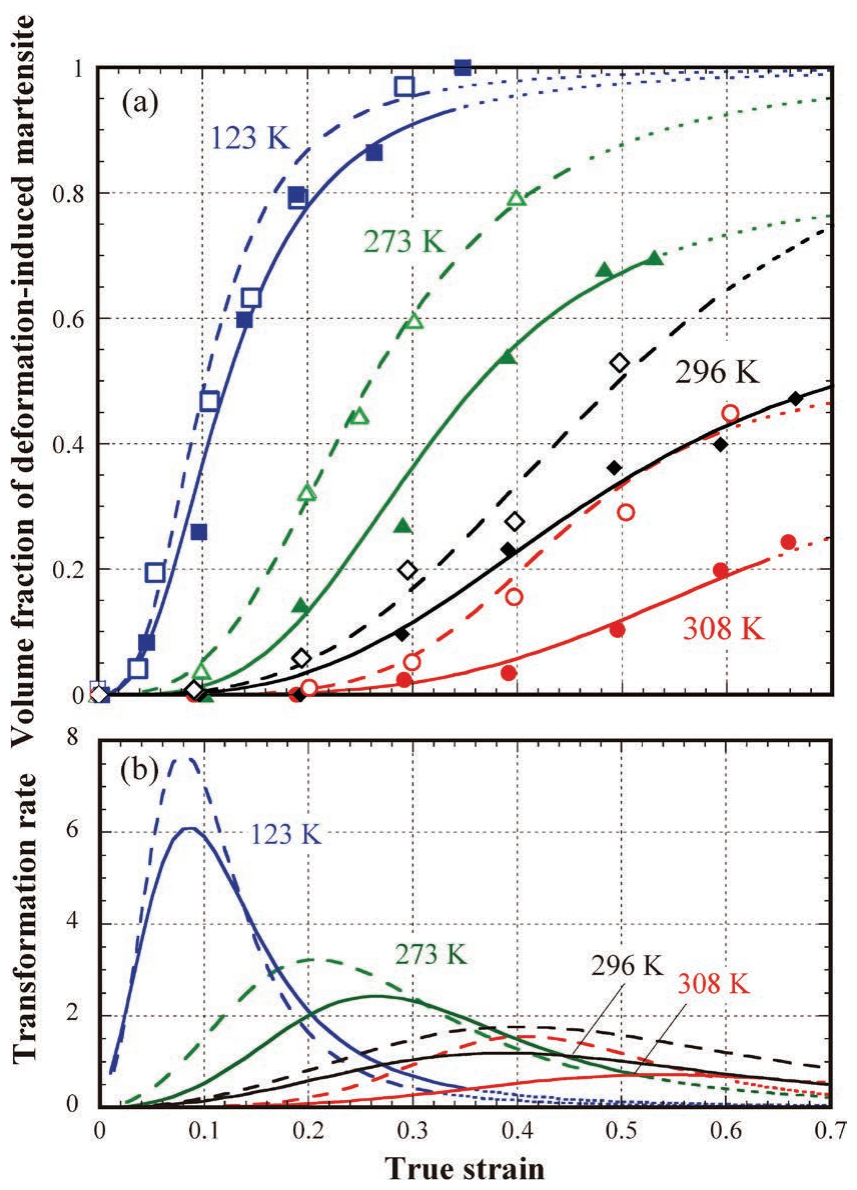

Fig. 6. Volume fraction of deformation-induced martensite (a) and rate of deformation-induced martensitic transformation (b) as functions of true strain at various temperatures in the $6 \mathrm{Ni}-0.2 \mathrm{~N}-0.1 \mathrm{C}$ and SUS304 ${ }^{11)}$ steels. (Online version in color.) 


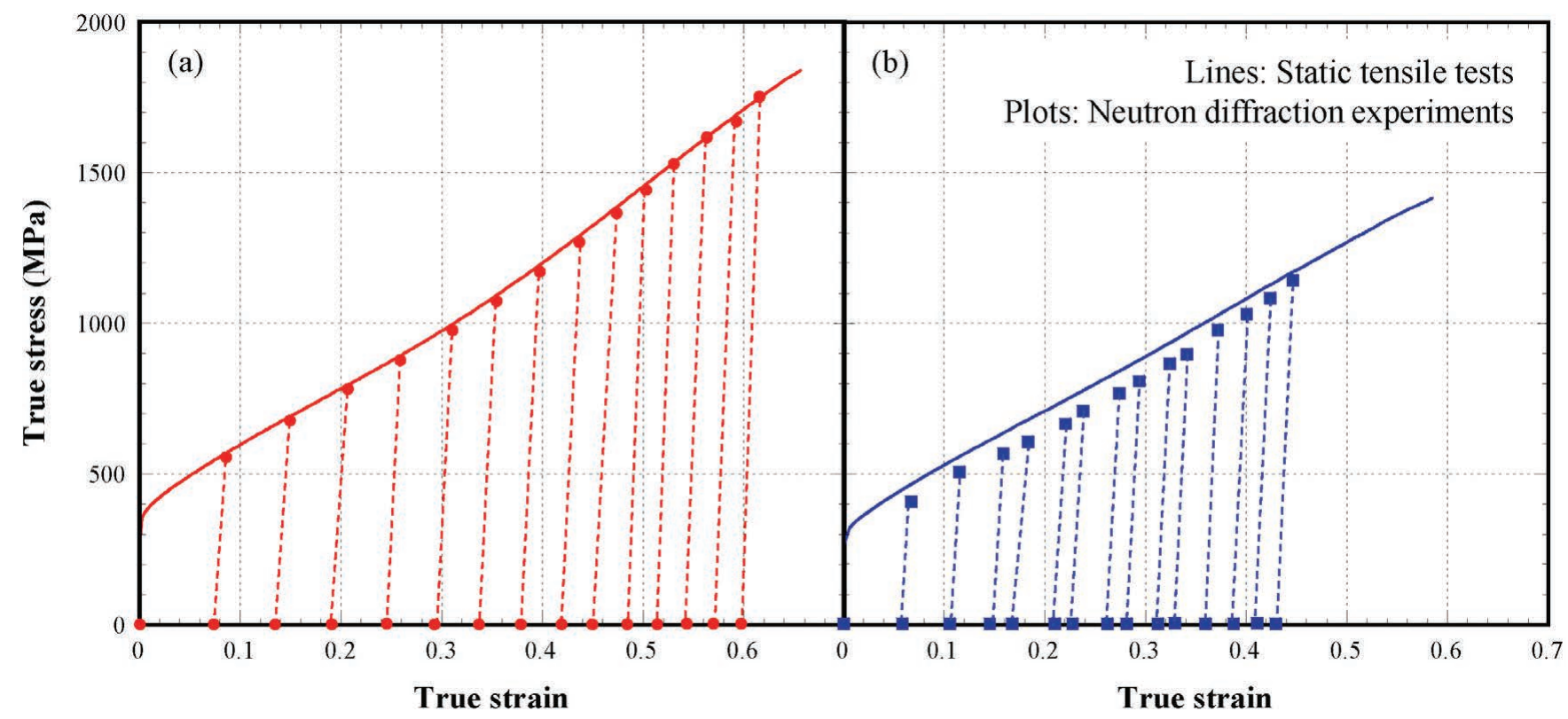

Fig. 7. True stress-true strain relationship obtained by the neutron diffraction experiments and the static tensile tests in the $6 \mathrm{Ni}-0.2 \mathrm{~N}-0.1 \mathrm{C}$ (a) and the SUS304 (b) ${ }^{11)}$ steels. (Online version in color.)

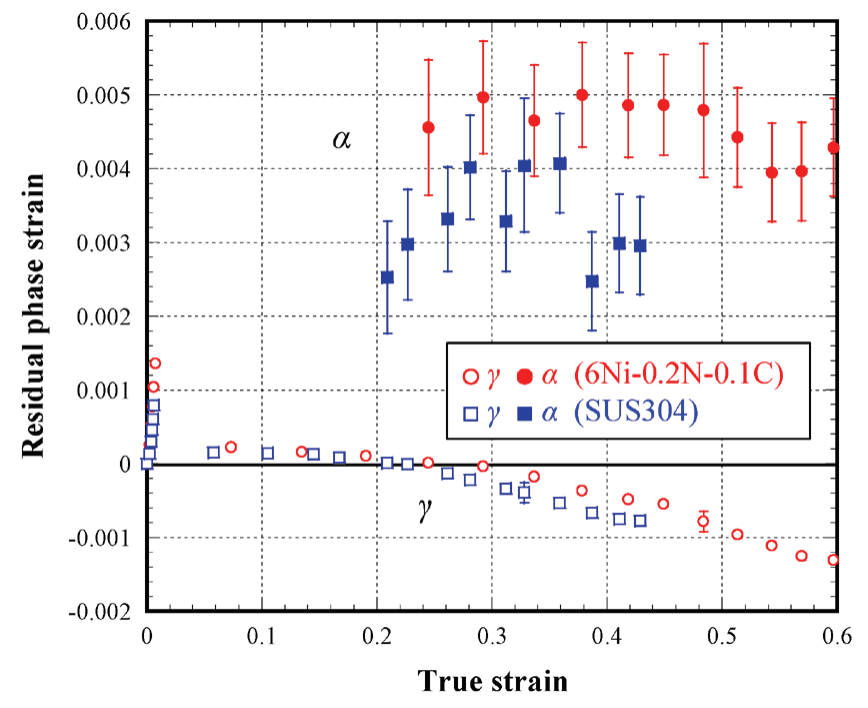

Fig. 8. Residual phase strains vs. true strain in the $6 \mathrm{Ni}-0.2 \mathrm{~N}-$ $0.1 \mathrm{C}$ and SUS304 steels obtained by the neutron diffraction experiments at room temperature. (Online version in color.)

ing behavior of each phase in term of the differences in the residual lattice strains among the grains. ${ }^{18,29,30)}$ As can be seen, the difference in the residual lattice strains for the $\gamma$ phase in the $6 \mathrm{Ni}-0.2 \mathrm{~N}-0.1 \mathrm{C}$ steel is larger than that in the SUS304 steel. This leads to a larger work hardening of the $\gamma$ phase in the $6 \mathrm{Ni}-0.2 \mathrm{~N}-0.1 \mathrm{C}$ steel compared with that in SUS304. The differences of residual lattice strains of the $\alpha$ phase were almost the same between the two steels. But the residual lattice strain of each grain at a given $\varepsilon$ was larger in the $6 \mathrm{Ni}-0.2 \mathrm{~N}-0.1 \mathrm{C}$ steel. Figure 10 shows a plot of $V_{\alpha}$ vs. $\varepsilon$ obtained from the neutron diffraction experiments with the $6 \mathrm{Ni}-0.2 \mathrm{~N}-0.1 \mathrm{C}$ and SUS304 steels at RT. The value of $V_{\alpha}$ at a given $\varepsilon$ was smaller in the $6 \mathrm{Ni}-0.2 \mathrm{~N}-0.1 \mathrm{C}$ steel, whereas the DIMT behaviors were almost the same as those calculated from x-ray diffraction experiments as seen in Fig. 6.
From the relationship between the residual phase strain and $\sigma$, the phase strains at a given $\sigma$ for the $\gamma$ and $\alpha$ phases were estimated by using the slope in the elastic regime $\left(E^{p h}\right){ }^{26)}$ The phase strains were estimated for the axial $\left(\varepsilon_{\text {axial }}^{\text {ph. }}\right)$ and transverse $\left(\varepsilon_{\text {transverse }}^{\text {ph. }}\right)$ directions, and the relationships between the phase strain and $\varepsilon$ were summarized. From the estimated phase strains, the phase stress for the tensile direction $\left(\sigma_{\text {axial }}^{p h}\right.$ ) was estimated by using the following equation,

$$
\sigma_{\text {axial }}^{p h .}=\frac{E^{p h .}}{\left(1+v^{p h \cdot}\right)\left(1-2 v^{p h \cdot}\right)}\left[\left(1-v^{p h .}\right) \varepsilon_{\text {axial }}^{p h .}+2 v^{p h .} \varepsilon_{\text {transverse }}^{p h .}\right] .
$$

where $E^{p h}$ and $v^{p h}$ are the elastic constant and Poisson's ratio, respectively, for each phase. ${ }^{26,28)}$ Figure 11 shows the estimated $\sigma_{\text {axial }}^{p h \text {. }}-\varepsilon$ relationships for the $\gamma$ and $\alpha$ phases in the $6 \mathrm{Ni}-0.2 \mathrm{~N}-0.1 \mathrm{C}$ and SUS304 steels at RT. Here, the estimated phase stress obtained from the neutron diffraction experiments is plotted, and the lines are the calculated $\sigma-\varepsilon$ curves obtained by using the following Swift equation, ${ }^{31)}$

$$
\sigma=a(b+\varepsilon)^{N}
$$

where $a, b$, and $N$ are constants. In a double-logarithmic plot of $\sigma_{\text {axial }}^{\text {ph. }}-\varepsilon$ data, the slope of the line gives the value of $N$ and the intercept at $\varepsilon=1$ gives the value of $a$. The value of $b$ was determined based on the previous studies. ${ }^{32,33)}$ The values of $a, b$ and $N$ used in Fig. 11 are summarized in Table 2. The phase stresses in both the $\gamma$ and $\alpha$ phases at a given $\varepsilon$ were larger in the $6 \mathrm{Ni}-0.2 \mathrm{~N}-0.1 \mathrm{C}$ steel. The difference in the phase stress of $\alpha$ between the $6 \mathrm{Ni}-0.2 \mathrm{~N}-$ $0.1 \mathrm{C}$ and SUS304 was approximately $1 \mathrm{GPa}$. We calculated the $\sigma-\varepsilon$ curves of the $6 \mathrm{Ni}-0.2 \mathrm{~N}-0.1 \mathrm{C}$ and SUS304 steels by using the secant method based on a micromechanics mode ${ }^{34,35)}$ to verify the estimated phase stresses in detail. The details of the calculation method based on the secant method for TRIP steels has been reported else- 


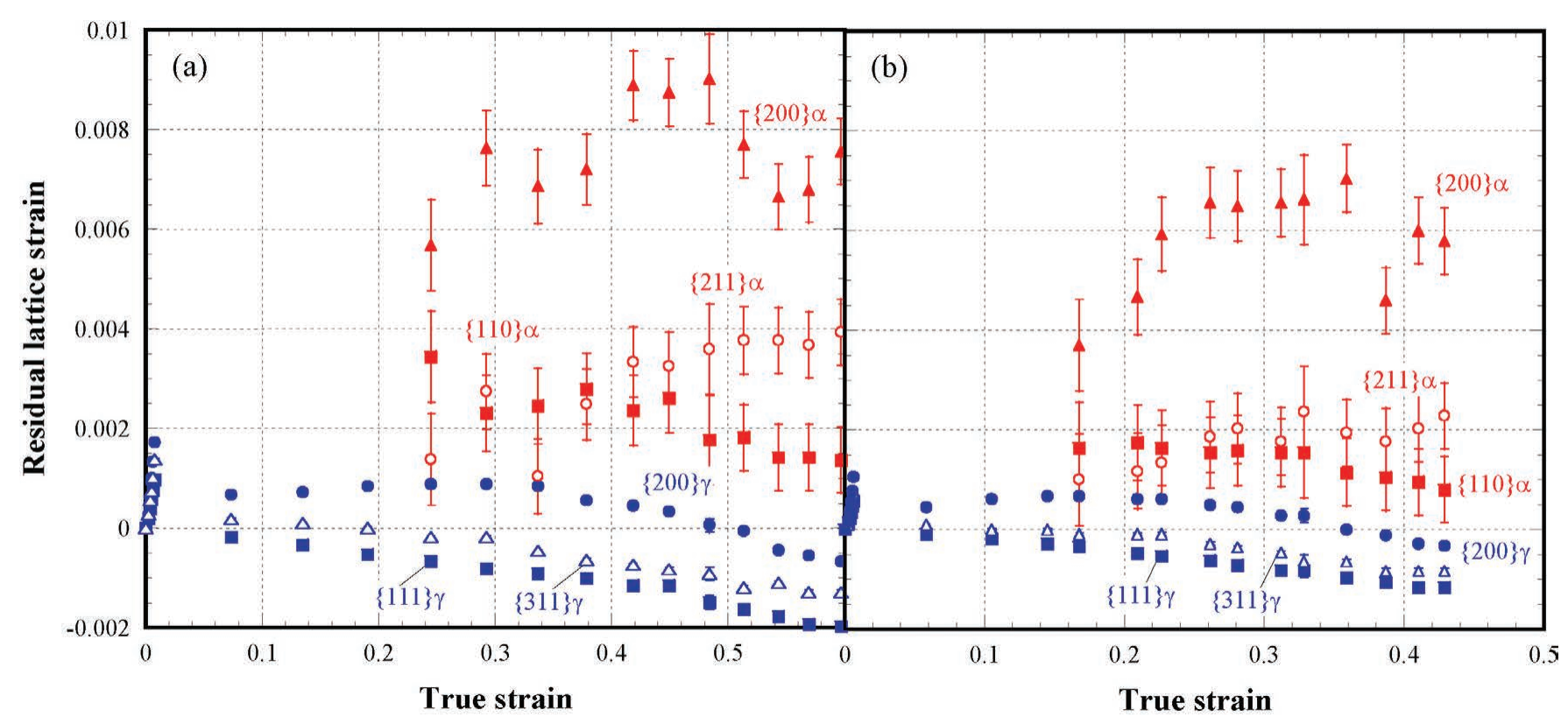

Fig. 9. Residual lattice strains vs. true strain in the $6 \mathrm{Ni}-0.2 \mathrm{~N}-0.1 \mathrm{C}$ (a) and SUS304 (b) steels obtained by the neutron diffraction experiments at room temperature. (Online version in color.)

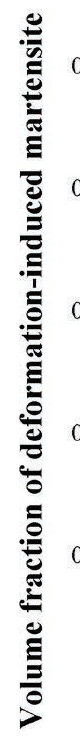



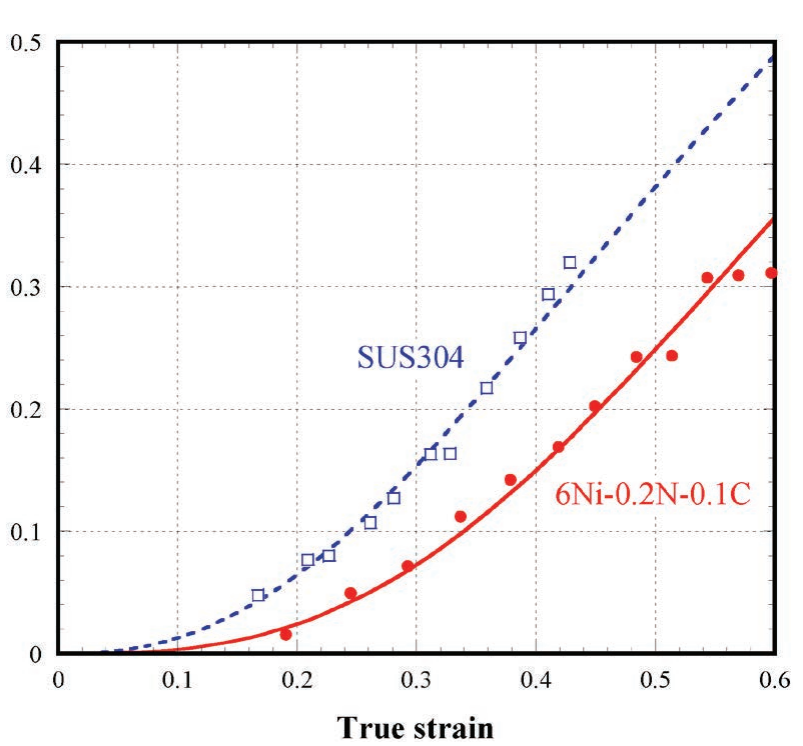

Fig. 10. Volume fraction of deformation-induced martensite as a function of true strain at room temperature in the $6 \mathrm{Ni}-0.2 \mathrm{~N}-0.1 \mathrm{C}$ and SUS304 steels obtained by the neutron diffraction experiments. (Online version in color.)

where. ${ }^{34-36)}$ The input data for the $\sigma-\varepsilon$ curves for $\gamma$ and $\alpha$ phases calculated by using Eq. (5) and the DIMT kinetics calculated by using Eq. (3) $)^{27)}$ are summarized in Table 2. Figure 12 shows comparisons between the calculated $\sigma-\varepsilon$ curves and the measured ones for the $6 \mathrm{Ni}-0.2 \mathrm{~N}-0.1 \mathrm{C}$ and SUS304 steels at RT. As can be seen, the calculated $\sigma-\varepsilon$ curves were in good agreement with the measured ones. Therefore, the tensile deformation behavior of the present two steels can be discussed from the estimated $\sigma-\varepsilon$ relationships of the $\gamma$ and $\alpha$ phases in Fig. 11. From Figs. 8,9 , and 11 , the better combination of TS and U.El in the $6 \mathrm{Ni}-0.2 \mathrm{~N}-0.1 \mathrm{C}$ steel can be explained by the larger strength of $\alpha$ and the larger work hardening behavior of $\gamma$. Furthermore, we examined the effects of the work harden-

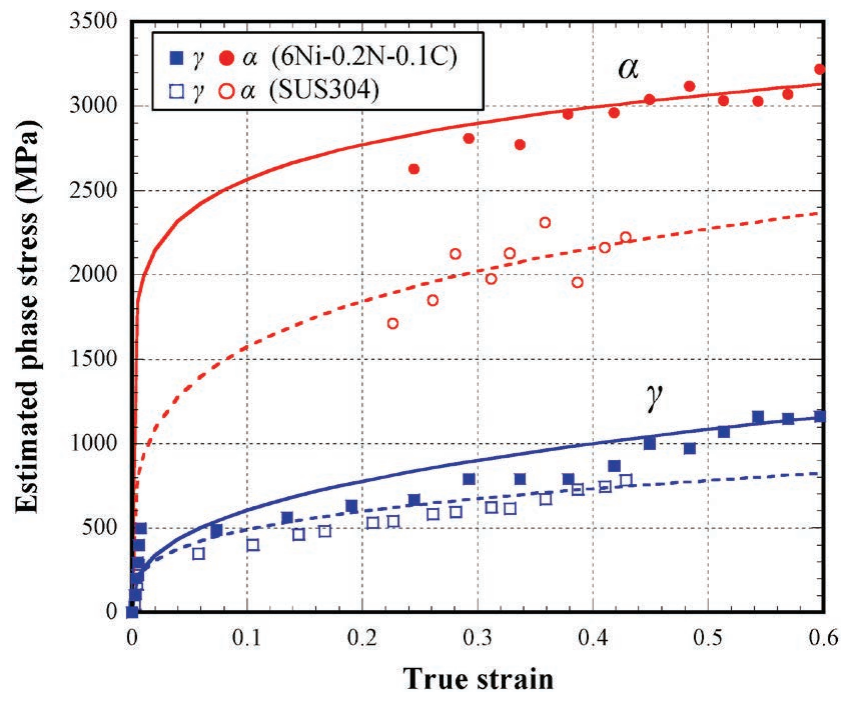

Fig. 11. Estimated phase stress of austenite $(\gamma)$ and deformationinduced martensite $(\alpha)$ phases vs. true strain in the $6 \mathrm{Ni}-0.2 \mathrm{~N}-0.1 \mathrm{C}$ and SUS304 steels obtained by the neutron diffraction experiments. (Online version in color.)

Table 2. $\quad a, b$ and $N$ in the Eq. (5) and $k$ and $q$ in the Eq. (3) used in the calculations of true stress-true strain curves of the $6 \mathrm{Ni}-0.2 \mathrm{~N}-0.1 \mathrm{C}$ and the SUS304 steels of Figs. 12 and 13.

\begin{tabular}{ccccccc}
\hline & phase & $a$ & $b$ & $N$ & $k$ & $q$ \\
\hline \multirow{2}{*}{ 6Ni-0.2N-0.1C } & $\gamma$ & 1393 & 0.002 & 0.363 & & \\
& $\alpha$ & 3311 & $10^{-7}$ & 0.111 & & \\
\hline \multirow{2}{*}{ SUS304 } & $\gamma$ & 955 & 0.002 & 0.29 & & \\
& $\alpha$ & 2661 & $10^{-7}$ & 0.229 & & \\
\hline
\end{tabular}

ing behavior of $\gamma$ and the strength of $\alpha$ on the TS and U.El for the $6 \mathrm{Ni}-0.2 \mathrm{~N}-0.1 \mathrm{C}$ steel from calculations. Figure 13 shows the calculated $\sigma-\varepsilon$ curves and $\mathrm{d} \sigma / \mathrm{d} \varepsilon$ obtained by the secant method. Calc. 1 is the same as that for the $6 \mathrm{Ni}-0.2 \mathrm{~N}-0.1 \mathrm{C}$ steel in Fig. 12. In Calc. 2, which is based 


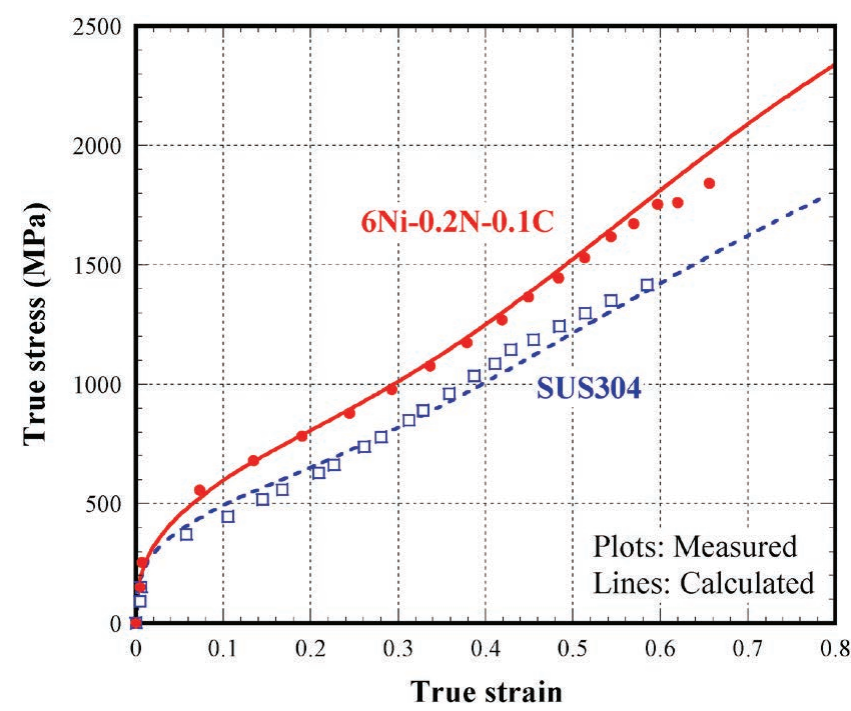

Fig. 12. Calculated true stress-true strain curves and measured ones in the $6 \mathrm{Ni}-0.2 \mathrm{~N}-0.1 \mathrm{C}$ steel and the SUS304 one. (Online version in color.)

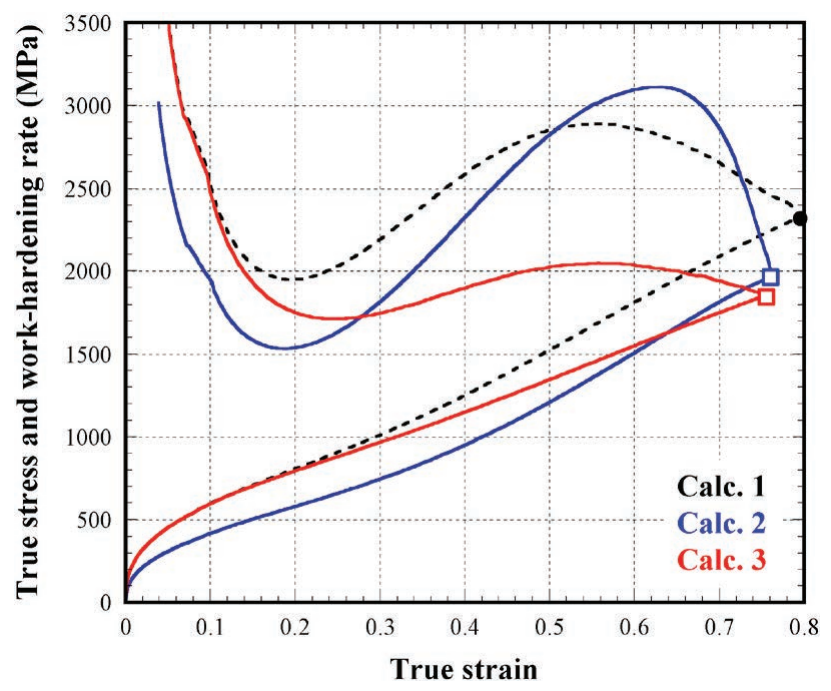

Fig. 13. Effects of austenite and deformation-induced martensite on the calculated true stress-true strain curve in the $6 \mathrm{Ni}-0.2 \mathrm{~N}-0.1 \mathrm{C}$ steel. (Online version in color.)

on Calc. 1 , the $\sigma-\varepsilon$ curve of $\gamma$ used in the calculation was changed to that of SUS304 in Fig. 12. The $\sigma-\varepsilon$ curve of $\alpha$ was changed to that of SUS304 in Calc. 3. In these calculations, the DIMT behavior was fixed as that of the $6 \mathrm{Ni}-0.2 \mathrm{~N}-0.1 \mathrm{C}$ steel, as seen in Fig. 10 and Table 2. The plastic instability condition, in which $\sigma$ is equal to $\mathrm{d} \sigma / \mathrm{d} \varepsilon$, shows TS and U.El in nominal stress-strain curves. ${ }^{37)}$ The decreases in U.El from Calc. 1 were almost the same as those in Calcs. 2 and 3. This means that the effects of the work hardening behavior of $\gamma$ and the strength of $\alpha$ on the $\mathrm{U} . \mathrm{El}$ in the $6 \mathrm{Ni}-0.2 \mathrm{~N}-0.1 \mathrm{C}$ steel are almost identical. On the other hand, the values of TS obtained from Calc. 2 were a little larger than those from Calc. 3, showing that the TS of the $6 \mathrm{Ni}-0.2 \mathrm{~N}-0.1 \mathrm{C}$ steel was influenced by the strength of $\alpha$. Yoshitake et al. ${ }^{21)}$ and Masumura et al. ${ }^{22,23)}$ investigated the stress-strain relationship and DIMT behavior of austenitic stainless steels containing $\mathrm{N}$ or $\mathrm{C}$. In the cases of 0.1 mass $\% \mathrm{~N}$ or $\mathrm{C}$, the effect of $\mathrm{C}$ content on mechanical stability of austenite was a little higher than the effect of $\mathrm{N}$, and the austenitic steel containing 0.1 mass $\%$ $\mathrm{C}$ indicated larger strength and elongation. $\left.{ }^{23}\right)$ They discussed those differences from the viewpoint of deformed microstructure and their results seem to be associated with the estimated $\sigma_{\text {axial }}^{\text {ph. }}$ of $\alpha$ as seen in Fig. 11. From the neutron diffraction experiments and the calculated results, we conclude that an increase of the strength of $\alpha$ due to the additions of $\mathrm{N}$ and $\mathrm{C}$ is very effective for obtaining the better combination of TS and U.El for the $6 \mathrm{Ni}-0.2 \mathrm{~N}-$ $0.1 \mathrm{C}$ steel, even though the $V_{\alpha}$ is smaller. The mechanical properties of duplex stainless steels with $0.2-0.5$ mass $\%$ $\mathrm{N}$, as studied by Tsuchida et al. $^{16)}$ and by Fujisawa et al. ${ }^{17)}$ also seem to be closely associated with the results of the present study. Because the $\mathrm{N}$ contents of $\gamma$ in duplex stainless steels are more than 0.3 mass $\%,{ }^{16,17)}$ both of the strength of $\alpha$ and the work hardening of $\gamma$ can be increased compared with those of the present $6 \mathrm{Ni}-0.2 \mathrm{~N}-0.1 \mathrm{C}$ steel. Therefore, a better uniform elongation can be obtained by the TRIP effect in the duplex stainless steels, even if the $V_{\alpha}$ is about $40 \%{ }^{16,17)}$

\section{Summary}

In this study, $\mathrm{Fe}-18 \mathrm{Cr}-6 \mathrm{Ni}-0.2 \mathrm{~N}-0.1 \mathrm{C}$ steel was prepared with a Ni content 2 mass \% lower than that of SUS304, and 0.2 mass $\%$ of $\mathrm{N}$ and 0.1 mass $\% \mathrm{C}$ were added. The effects of temperature on the tensile properties and the TRIP effect in this steel were investigated by tensile testing at various temperatures between 123 and $373 \mathrm{~K}$. The main conclusions are as follows:

(1) The mechanical properties $(0.2 \%$ proof stress, tensile strength (TS), and uniform elongation (U.El)) at all temperatures were larger in the $6 \mathrm{Ni}-0.2 \mathrm{~N}-0.1 \mathrm{C}$ steel. The volume fraction of deformation-induced martensite $(\alpha)$ at a given temperature and the true strain were smaller in the $6 \mathrm{Ni}-0.2 \mathrm{~N}-0.1 \mathrm{C}$ steel.

(2) From neutron diffraction experiments at room temperature, the work hardening behavior of austenite $(\gamma)$, in terms of the difference of residual lattice strains, and the strength of $\alpha$, in terms of the residual phase strain, were larger in the $6 \mathrm{Ni}-0.2 \mathrm{~N}-0.1 \mathrm{C}$ steel. These two points are the main reasons for the better TS and U.El of the $6 \mathrm{Ni}-0.2 \mathrm{~N}-0.1 \mathrm{C}$ steel compared with those of the SUS304 steel.

(3) The additions of $\mathrm{N}$ and $\mathrm{C}$ in austenite steels contribute to not only a higher mechanical stability and a larger work hardening of in $\gamma$ but also an increase in the strength of $\alpha$. This leads to the better combination of TS and U.El by the TRIP effect with a smaller volume fraction of $\alpha$. The additions of $\mathrm{N}$ and $\mathrm{C}$ are important for achieving effective use of the TRIP effect from the viewpoints other than the deformation-induced transformation behavior.

\section{Acknowledgments}

The authors are grateful to Mr. R. Bajo of undergraduate student of University of Hyogo, Dr. R. Ueji of National Institute for Materials Science, Drs. K. Aizawa, S. Harjo, T. Kawasaki and G. Wu of J-PARC center, Japan Atomic Energy Agency for their helps and valuable discussions. The neutron diffraction experiments were performed at J-PARC/MLF beamline in JAEA (Proposal No. 
2014P0102).

\section{REFERENCES}

1) T. Angel: J. Iron Steel Inst., 177 (1954), 165.

2) V. F. Zackay, E. R. Parker, D. Fahr and R. Bush: Am. Soc. Met. Trans. Q., 60 (1967), 252.

3) I. Tamura: Met. Sci., 16 (1982), 245

4) T. S. Byun, N. Hashimoto and K. Farrell: Acta Mater., 52 (2004), 3889 .

5) J. Talonen, H. Hanninen, P. Nenonen and G. Pape: Metall. Mater. Trans. A, 36 (2005), 421

6) G. L. Huang, D. K. Matlock and G. Krauss: Metall. Trans. A, 20 (1989), 1239.

7) K. Sugimoto, M. Kobayashi and S. Hashimoto: Metall. Trans. A, 23 (1992), 3085

8) O. Matsumura, Y. Sakuma and H. Takechi: Trans. Iron Steel Inst. Jpn., 27 (1987), 570

9) J. A. Jimenez, M. Carsi, O. A. Ruano and G. Frommeyer: Mater. Sci. Eng. A, 508 (2009), 195.

10) N. Tsuchida, T. Tanaka and Y. Toji: ISIJ Int., 60 (2020), 1349. https://doi.org/10.2355/isijinternational.ISIJINT-2019-751

11) N. Tsuchida, Y. Morimoto, T. Tonan, Y. Shibata, K. Fukaura and R. Ueji: ISIJ Int., 51 (2011), 124.

12) N. Tsuchida, Y. Yamaguchi, Y. Morimoto, T. Tonan, Y. Takagi and R. Ueji: ISIJ Int., 53 (2013), 1881.

13) Y. Takagi, R. Ueji, T. Mizuguchi and N. Tsuchida: Tetsu-to-Hagané, 97 (2011), 450 (in Japanese).

14) N. Tsuchida, S. Kawabata, K. Fukaura and R. Ueji: J. Alloy. Compd., 577 (2013), Suppl. 1, S525.

15) S. Harjo, N. Tsuchida, J. Abe and W. Gong: Sci. Rep., 7 (2017), Article No. 15149. https://doi.org/10.1038/s41598-017-15252-5

16) N. Tsuchida, T. Kawahata, E. Ishimaru and A. Takahashi: ISIJ Int. 54 (2014), 1971.

17) M. Fujisawa, R. Mauchi, T. Morikawa, M. Tanaka and K. Higashida: Tetsu-to-Hagané, 100 (2014), 1140 (in Japanese).
18) N. Tsuchida, T. Kawahata, E. Ishimaru, A. Takahashi, H. Suzuki and T. Shobu: ISIJ Int., 53 (2013), 1260

19) T. H. Lee, C. S. Oh and S. J. Kim: Scr. Mater, 58 (2008), 110.

20) R. Miura, K. Ohnishi, H. Nakajima and S. Shimamoto: Tetsu-toHagané, 73 (1987), 715 (in Japanese).

21) M. Yoshitake, T. Tsuchiyama and S. Takaki: Tetsu-to-Hagané, 98 (2012), 223 (in Japanese).

22) T. Masumura, N. Nakada, T. Tsuchiyama, S. Takaki, T. Koyano and K. Adachi: Acta Mater., 84 (2015), 330. https://doi.org/10.1016/j. actamat.2014.10.041

23) T. Masumura, K. Fujino, T. Tsuchiyama, S. Takaki and K. Kimura: Tetsu-to-Hagané, 105 (2019), 1163 (in Japanese).

24) A. K. De, D. C. Murdock, M. C. Mataya, J. G. Speer and D. K. Matlock: Scr. Mater., 50 (2004), 1445.

25) W. Gong, Y. Tomota, S. Harjo, Y. H. Su and K. Aizawa: Acta Mater., 85 (2015), 243.

26) S. Morooka, O. Umezawa, S. Harjo, K. Hasegawa and Y. Toji: Tetsuto-Hagané, 98 (2012), 311 (in Japanese).

27) O. Matsumura, Y. Sakuma and H. Takechi: Scr. Mater., 21 (1987), 1301.

28) S. Harjo, Y. Tomota, P. Lukas, D. Neov, M. Vrana, P. Mikula and M. Ono: Acta Mater., 49 (2001), 2471

29) Y. Tomota, H. Tokuda, Y. Adachi, M. Wakita, N. Minakawa, A. Moriai and Y. Morii: Acta Mater., 52 (2004), 5737.

30) M. Ojima, Y. Adachi, Y. Tomota, K. Ikeda, T. Kamiyama and Y. Katada: Mater. Sci. Eng. A, 527 (2009), 16.

31) H. W. Swift: J. Mech. Phys. Solids, 1 (1952), 1.

32) M. Umemoto: Tetsu-to-Hagané, 81 (1995), 157 (in Japanese).

33) Y. Tomota, M. Umemoto, N. Komatsubara, A. Hiramatsu, N. Nakajima, A. Moriya, T. Watanabe, S. Nanba, G. Anan, K. Kunishige, Y. Higo and M. Miyahara: ISIJ Int., 32 (1992), 343.

$34)$ G. J. Weng: J. Mech. Phys. Solids, 38 (1990), 419.

35) N. Tsuchida and Y. Tomota: Mater. Sci. Eng. A, 285 (2000), 346.

36) N. Tsuchida. Y. Morimoto, S. Okamoto, K. Fukaura, Y. Harada and R. Ueji: J. Jpn. Inst. Met., 72 (2008), 769 (in Japanese).

$37)$ N. Tsuchida: Bull. Iron Steel Inst. Jpn., 21 (2016), 389 (in Japanese). 